COUNSENESIA
Indonesian Journal of Guidance and Counseling
www.ejournal.utp.ac.id/index.php/CIJGC

\title{
PERAN ROHANIWAN SEBAGAI KONSELOR DALAM PEMBERIAN LAYANAN KONSELING PASTORAL
}

\author{
Munik Yuni Artika \\ Universitas Negeri Semarang \\ Munikyuniartika12@gmail.com
}

\begin{abstract}
Info Artikel
Abstrak

Riwayat Artikel

Dalam konseling pastoral menekankan pada penguatan batiniah secara religiusitas Diterima:

Juni 2020

Disetujui:

xxxx 2020

Publikasi:

Juni 2020

DOI : (pastoral care) yang sangat dibutuhkan oleh umat beragama Konseling pastoral merupakan bentuk unik dari administrasi konseling yang dilakukan untuk membantu klien memperoleh kehidupan yang seimbang sebagai pribadi yang utuh. Keberadaan rohiawan menjadi suatu hal yang krusial bagi para jemaat Kristen. Sebab rohaniwan mengambil peran seseorang yang dianggap dapat membantu dan memberikan harapan pada jemaat. Selain itu rohiawan juga berperan sebagai konselor pastoral yang memiliki keunikan diantara konselor pada umumnya, baik dalam fungsi sosial maupun simbolis. Konselor pastoral yang bertugas di lembaga-lembaga publik dan melihat diri mereka sebagai teolog publik yang menanamkan nilai-nilai pastoral ke dalam layanan sosial dan pasar medis. Artikel ini merupakan sebuah gagasan konseptual yang pengumpulan datanya diperoleh dari artikel-artikel dari jurnal yang relevan dengan gagasan ini, dan diperkuat oleh wawancara dengan salah satu rohaniwan (romo), serta dokumentasi
\end{abstract}

Kata Kunci : Rohiawan, Konselor, Konseling Pastoral.

ABSTRACT

In pastoral counseling, it emphasizes the strengthening of the inner religiosity (pastoral care) that is needed by religious people Pastoral counseling is a unique form of counseling administration that is done to help clients obtain a balanced life as a whole person. The presence of a scholar is crucial for the Christian congregation. Because the clergy take the role of someone who is considered to be able to help and give hope to the congregation. In addition, Rohiawan also acts as a pastoral counselor who is unique among counselors in general, both in social and symbolic functions. Pastoral counselors who work in public institutions and see themselves as public theologians who instill pastoral values in social services and the medical market. This article is a conceptual statement that is combined with data obtained from articles from journals that are relevant to this opinion, and is supported by an interview with one of the priests (priest), as well as documentation

Keywords: Rohiawan, Counselor, Pastoral Counseling

(C) 2020 Universitas Tunas Pembangun Surakarta 


\section{PENDAHULUAN}

Dalam menjalani kehidupan, manusia tidak terlepas dari berbagai macam masalah yang menerpa. Tidak bisa dihindari jika suatu saat, mungkin saja masalah yang dihadapi terlalu berat sehingga terasa diluar batas kemampuan individu untuk menyelesaikan sendiri sehingga berdampak pada terganggunya keselarasan hidup. Dalam kondisi seperti ini dibutuhkan adanya konseling sebagai upaya pemberian bantuan. Konseling merupakan alat yang sangat baik bagi suatu organisasi maupun individu untuk mengatasi masalah yang dihadapi seseorang yang berada dalam kondisi tidak sehat secara mental spiritual.

Bidang konseling adalah disiplin yang luas dengan berbagai bidang fokus. Namun untuk keperluan masalah ini, hanya kompetensi konseling spesifik yang dikembangkan, yaitu konseling pastoral. David Benner (1992) menyatakan bahwa Konseling Pastoral melibatkan pembentukan suatu hubungan terbatas waktu yang terstruktur untuk memberikan kenyamanan bagi orang-orang yang bermasalah dengan meningkatkan kesadaran mereka akan rahmat Allah dan kehadiran yang setia dan dengan demikian meningkatkan kemampuan mereka untuk menjalani kehidupan mereka lebih penuh dalam terang kesadaran-kesadaran ini. Konseling pastoral adalah bentuk unik dari administrasi konseling yang dilakukan untuk membantu klien memperoleh kehidupan yang seimbang sebagai pribadi yang utuh (Pedhu, 2019).

Dalam konseling pastoral menekankan pada penguatan batiniah secara religiusitas (pastoral care) yang sangat dibutuhkan oleh umat beragama. Tak heran jika para rohaniwan disepanjang sejarah dan di semua tempat telah melayani banyak masalah pribadi yang dialami umat paroki. Namun faktanya, tidak semua gereja menyediakan layanan konseling pastoral, atau pelayanan yang dilakukan sangat terbatas. Akibatnya para jemaat tidak dapat memperoleh layanan konseling pastoral seperti yang mereka butuhkan. Bahkan dibeberapa kasus para rohaniwan terkesan membuat jarak dengan para jemaat, sehingga para jamaat merasa segan untuk bertemu dengan para rohaniwan yang berkompeten dalam memberikan layanan konseling pastoral tersebut. Di sisi lain, gereja yang memiliki anggota dalam jumlah besar dan tidak diimbangi dengan jumlah rohaniwan yang memadai, untuk masalah-masalah yang berkaitan dengan mental spiritualnya, para jemaat lebih menyukai dan lebih merasa sejahtera bila dapat berkonsultasi dengan para konselor non kristiani, seperti psikolog, dokter, teman, ataupun orang lain yang tidak kompeten sebagai konselor kristen. Inilah suatu kenyataan yang merupakan tantangan bagi pihak gereja dalam bidang pendampingan pastoral dan konseling pastoral (Gunawan, 2018).

Dalam pemberian layanan konseling pastoral, rohaniwan berperan sebagai konselor. Rohaniwan yang dimaksud adalah orang yang mendampingi sesama manusia lain dengan menggunakan pendekatan keagamaan. Konselor kristen, memiliki keunikan dibandingkan dengan konselor yang bukan kristen. Beberapa aspek yang membedakan antara lain adalah adanya sifat-sifat konselor kristen seperti: mengakui firman Tuhan sebagai standar utama, bersandar pada Tuhan dan Roh Kudus, memiliki iman, melayani berdasarkan kasih Allah, melayani berdasarkan manusia yang memiliki tubuh, jiwa, dan roh, serta mengerti Firman Tuhan. Hal ini sesuai fungsi dasar yang digambarkan dalam empat fungsi dasariah Gereja ; a) persaudaraan, b) pewarta injil, c) ibadah, dan d) pelayanan kepada masyarakat (Timur \& Wardana, 2019).

Pemahaman konselor pastoral tentang identitasnya tampaknya tergantung pada konteks praktik profesional. Orang-orang yang berpraktik di lingkungan jemaat atau pusat-pusat yang berafiliasi dengan gereja cenderung mengaitkan identitas dengan cara-cara gerejawi yang jelas dan sering menggunakan gelar agama untuk membantu membangun 
kepercayaan. Konselor pastoral yang bertugas di lembaga-lembaga publik mengidentifikasi diri mereka sebagian besar melalui lisensi negara (LMFT, LPC, LCSW, atau Psikolog) dan melihat diri mereka sebagai teolog publik yang menanamkan nilai-nilai pastoral ke dalam layanan sosial dan pasar medis (Townsend, 2015).

Dasar pelayanan rohaniwan bahwa pertumbuhan rohani merupakan pondasi seluruh kesatuan manusia, dan pada saat yang sama, terkait dengan seluruh aspek kesatuan yang lain. Tidak ada bidang kehidupan yang tidak memiliki kepentingan religious. Oleh karena itu, tidak ada bidang kehidupan yang tidak relevan dengan konseling pastoral. para konselor pastoral mempunyai perhatian utama dalam memfasilitasi pertumbuhan rohani tidak berarti agar mereka hanya memerhatikan atau mengutamakan persoalan-persoalan yang tampaknya rohani. Semua persoalan mempunyai unsur rohani karena seluruh kehidupan bersifat religius atau rohani. Apalagi, persoalan-persoalan rohani muncul paling jelas dalam konteks pengalaman dan pergumulan hidup sehari-hari, dan keduanya merupakan fokus alami hubungan konseling. Untuk memunculkan fokus rohani ini ke dalam topik yang sedang dibahas membutuhkan keterampilan yang besar dari pihak rohaniwan selaku konselor konseling pastoral (Benner, 1992).

\section{HASIL DAN PEMBAHASAN}

Peneliti melakukan wawancara dengan salah satu rohaniwan (Romo HYSS/ 39 th) yang ada digereja Katedral, Semarang Jawa Tengah. Rohaniwan menuturkan bahwa Untuk memperoleh ilmu keagamaan, rohaniwan harus menjalani pendidikan yang dilaksanakan oleh gereja, pendidikan pendampingan kehidupan baik itu kehidupan rohani maupun kehidupan sehari-sehari dalam suatu seminar dan menjalani karantina diasrama. Selain itu, rohaniwan juga dituntut untuk memiliki keterampilan dasar guna menunjang keberhasilan konseling pastoral. Rohaniwan juga menyertakan ilmu pengetahuan psikologi dan konseling yang mereka dapatkan dimasa studi. Ketika masa studi calon rohaniwan diajarkan tentang iman, hukum gereja dan moral gereja juga dilengkapi dengan ilmu-ilmu psikologi dan konseling sebagai bekal dalam melakukan pengakuan dosa dan pemberian layanan konseling pastoral.

Peran rohaniwan ibarat dokter umum yang menangani macam-macam keluhan pasiennya. Tidak ada bidang khusus yang dimiliki rohaniwan dalam pemberian layanan konseling pastoral, sebab masalah yang dialami konseli sifatnya sangat kompleks, seputar keluarga, mendampingi anak, pekerjaan, studi motivasi hidup dan masalah-masalah lain dalam kehidupan sehari-hari. Jika rohaniwan menemukan masalah yang berat pada konselinya dan merasa kurang mampu untuk menyelesaikannya, maka konseli akan direveral kepada rohaniwan lain, atau bahkan psikolog maupun konselor yang lebih berkompeten dan sekiranya mampu untuk menindaklanjuti masalah konseli tersebut.

Hasil wawancara mengkonfirmasi bahwa rohaniwan tidak hanya berperan untuk menuntun konseli dalam pengampunan dosa saja, namun juga berperan dalam pemberian layanan konseling pastoral. Layanan konseling dapat diberikan sebelum atau sesudah pengakuan dosa. Ketika konseli membutuhkan bantuan untuk menindaklanjuti permasalahannya yang disampaikan dalam ruangan pengakuan dosa, maka rohaniwan akan menindaklanjuti dengan pemberian layanan konseling pastoral. Seperti halnya konselor, para rohaniwan disumpah untuk tidak menyebarkan apapun yang mereka ketahui atau mereka dengar di ruangan pengakuan dosa, begitupun dalam pelaksanaan konseling. Sebab asas kerahasiaan sangat dijunjung tinggi.

Dalam pelaksanaan layanan konseling pastoral, rohaniwan tidak hanya menggunakan Alkitab sebagai landasan konseling. Didalam konseling, alkitab bisa 
digunakan untuk pemberian pengakuan dosa dan dijadikan sebagai tuntunan soal kehidupan secara lebih luas, namun tidak secara teknis dan praktis. Maka dari itu, rohaniwan bisa menggunakan hukum gereja, dimana hukum gereja ini memberikan acuan-acuan untuk memecahkan dan menyelesaikan masalah. Selain hukum gereja, romo akan menggunakan moral gereja, dimana ajaran moral gereja mengarahkan konseli pada ajaran-ajaran gereja, ajaran iman, ajaran moral. Jadi dalam konseling pastoral, konselor mengintegrasikan antara hukum gereja dan moral gereja, serta menyesuaikan landasan tersebut dengan masalah yang dimiliki konseli.

\section{PEMBAHASAN}

Konseling pastoral dipandang sebagai spesialisasi yang meliputi teologi, iman, dan psikoterapi dan melahirkan suatu hubungan di mana para rohaniwan akan bertemu langsung dengan para jemaat untuk membantu mereka mengatasi berbagai masalah sosial-emosional dan masalah-masalah yang berkaitan dengan iman (Stansbury dkk, 2012). Dalam layanan konseling pastoral melibatkan pendampingan orang-orang yang bermasalah, sedangkan implementasinya dengan mendengarkan secara aktif dan berusaha membantu konseli dengan menuntun dan memberikan pertimbangan pilihan untuk masalah mereka. Hal tersebut senada dengan sasaran utama konseling pastoral. Sasaran utama konseling pastoral adalah pemfasilitasan pertumbuhan rohani yang mencakup menolong para konseli untuk memahami persoalan dan kehidupan mereka dengan mengingat hubungan mereka dengan Allah, kemudian hidup lebih sungguh dalam hubungan tersebut.

Benner (2003) menjelaskan beberapa fitur utama yang membuatnya berbeda dari layanan konseling lainnya, salah satunya adalah pelatihan konselor pastoral. Konselor pastoral adalah satu-satunya profesional yang memiliki pelatihan dalam teologi sistematika, studi Alkitab, etika, dan sejarah gereja. Karena itu, konselor pastoral harus mengintegrasikan elemen-elemen itu dalam praktik konseling mereka. Kegagalan untuk mengintegrasikan dimensi-dimensi tersebut menunjukkan bahwa konseling pastoral telah kehilangan identitas dan keunikannya (Pedhu, 2019). Hal ini dikuatkan dengan pendapat Howard Clinebell dalam buku ajarnya Tipe Dasar Perawatan dan Konseling Pastoral, mengemukakan bahwa bagi para rohaniwan penting untuk mendapatkan pelatihan terbaik yang tersedia dalam konseling, baik secara akademis dan klinis, tidak hanya untuk menghindari bahaya, tetapi untuk memaksimalkan kemampuan seseorang sebagai alat penyembuhan (Younce, 2012).

Peran rohaniwan juga memiliki keunikan di antara para konselor dalam fungsi sosial dan simbolis mereka. Mereka adalah sosok pemimpin agama dan secara simbolis mereka melambangkan nilai-nilai dan keyakinan-keyakinan religius. Oleh karena itu, orang-orang yang mendekati rohaniwan memiliki harapan yang berbeda dibandingkan mereka yang datang kepada orang-orang yang tergabung dengan para ahli konseling atau psikolog pada umumnya.

Implementasi konseling pastoral memiliki khas tersendiri karena menggunakan sumber-sumber religius yang dijadikan sebagai sumber-sumber potensial untuk proses konseling, namun sebelum menggunakan sumber religious rohiawan perlu menyesuaikan dengan kebiasaan religius konselinya. Rohiawan harus menggunakan dengan hati-hati dan bijak serta perlu memahami sumber-sumber tersebut secara tepat. Penggunaan sumber-sumber religius secara tepat dalam konseling didahului dengan sadarnya rohiawan terhadap persoalan konseli dan latar belakang religiusnya sekaligus sikapnya terhadap agama saat itu. sumber-sumber religius sebaiknya digunakan dengan cara-cara 
yang menguatkan konseli alih-alih dengan cara-cara yang mungkin mengecilkan prakarsa, kekuatan, atau tanggung jawabnya.

\section{Simpulan}

Konseling Pastoral melibatkan pembentukan suatu hubungan terbatas waktu yang terstruktur untuk memberikan kenyamanan bagi orang-orang yang bermasalah dengan meningkatkan kesadaran mereka akan rahmat Allah dan kehadiran yang setia dan dengan demikian meningkatkan kemampuan mereka untuk menjalani kehidupan mereka lebih penuh dalam terang kesadaran-kesadaran ini. Keberadaan rohiawan menjadi suatu hal yang krusial bagi para jemaat Kristen. Sebab rohaniwan mengambil peran seseorang yang dianggap dapat membantu dan memberikan harapan pada jemaat. Selain itu rohiawan juga berperan sebagai konselor pastoral yang memiliki keunikan diantara konselor pada umumnya, baik dalam fungsi sosial maupun simbolis. Konselor pastoral yang bertugas di lembaga-lembaga publik dan melihat diri mereka sebagai teolog publik yang menanamkan nilai-nilai pastoral ke dalam layanan sosial dan pasar medis.

\section{DAFTAR PUSTAKA}

Benner G. David (1992) Strategic Pastoral Counseling, Baker Book House; Michigan. https://sabda.org/c3i/keunikan konseling pastoral

Palit, S. R. (2019). Pendekatan Pelayanan Tuhan Yesus Dalam Perspektif Pastoral Konseling. Jurnal Teologi Rahmat, 5(1), 54-70.

Pedhu, Y. (2019). Efforts to Overcome Countertransference in Pastoral Counseling Relationships. Journal of Pastoral Care \& Counseling, 73(2), 74-81.

Stansbury, K. L., Harley, D. A., King, L., Nelson, N., \& Speight, G. (2012). African American clergy: what are their perceptions of pastoral care and pastoral counseling?. Journal of religion and health, 51(3), 961-969.

Townsend, L. L. (2011). A grounded theory description of pastoral counseling. Journal of Pastoral Care \& Counseling, 65(3), 1-15.

Timur, A. R., \& Wardana, A. (2019). Peran Rohaniwan Kristiani Dalam Penguatan Religiusitas Pasien Rumah Sakit Ngesti Waluyo Temanggung. E-Societas, 8(2).

Wijayatsih, H. (2012). Pendampingan Dan Konseling Pastoral. Gema Teologi, 35(1/2).

Younce, C. L. (2012). The significance of developing core counseling competencies in pastoral care ministry. 